\title{
A Review on Problems of the Public Building Maintenance Works with Special Reference to Nepal
} \author{
Nepal \\ Email address: \\ rcdahal77@gmail.com (R. C. Dahal) \\ ${ }^{*}$ Corresponding author
}

Ram Chandra Dahal ${ }^{*}$, Khet Raj Dahal

Department of Construction Engineering and Management (CEM), Lumbini International Academy of Science and Technology, Lalitpur,

\section{To cite this article:}

Ram Chandra Dahal, Khet Raj Dahal. A Review on Problems of the Public Building Maintenance Works with Special Reference to Nepal. American Journal of Construction and Building Materials. Vol. 4, No. 2, 2020, pp. 39-50. doi: 10.11648/j.ajcbm.20200402.12

Received: July 8, 2020; Accepted: August 4, 2020; Published: August 18, 2020

\begin{abstract}
The study was conducted during the period from the month of March to April 2020. Published literatures such as thesis, paper, manuals, reports, and database were collected from different sources and studied thoroughly. The conclusions were drawn on the basis of the studied materials. The study found that the public buildings of any nation are too valuable assets and maintaining them at regular functional state is becoming challenging job for developing countries like Nepal. The most significant building maintenance problems are: plumbing and w/s, toilet, bathroom and sanitary, electrical problems, poor maintenance management and practices, peeling of paint, dampness, surface cracking, growth of fungi or small plants and decay or breaking of floor/tile. Decay, deterioration and failure of the fabric and finishing of a building due to negligence of maintenance have harmful effects on the contents and occupants. Causes of maintenance problems can be grouped as managerial, technical, building user related and natural causes. There are major causes such as design defects, inadequate contractor and construction supervision, use of low quality materials and workmanship, unavailability of qualified human resources and quality materials, poor maintenance management, insufficient maintenance fund but high and unexpected cost, age of building, natural disaster and earth settlement and so on. Lack of proper maintenance department, programs, plan and policy are the critical issues of improvement by public institutions. Patent and latent defects in buildings are serious issues and failure to address them would contribute to additional rectification cost, hamper the smooth operation of the building and reduce its service life. Buildings and facilities that are not properly maintained can cause discomfort and lead to accidents and injury to the users. The study would like to suggest that the handling of maintenance problems should be minimized by identifying the root causes and applying the effective and efficient maintenance management program. Precaution should be applied at design and construction stage ensuring quality construction and delivery with all building documents. Furthermore, each public institution should formulate maintenance objectives, apply suitable strategy, manage adequate resources, develop maintenance action plan, periodic review of performance and strategy at service stage.
\end{abstract}

Keywords: Public Buildings, Maintenance Policy and Practices, Maintenance Strategy, Preventive Maintenance

\section{Introduction}

The changes in construction engineering revolution have been hugely affected by the ways and standards the constructed facilities have been maintained. Prior to World War-II, maintenance was carried out on 'breakdown basis'. From the 1950 onwards, construction industry demanded better maintenance which led to the development of 'planned preventive maintenance' [1]. From 1960, 'reliability centered maintenance' was practiced and from 1980, maintenance has been transited from 'reactive to strategic' approach with effective maintenance programs.

Maintenance is the combination of all technical, administrative and managerial actions during the life cycle of any construction facility that has aimed in retaining or restoring to perform the required functions. This definition clarifies the objectives of maintenance and lays focus on that part of organization which requires maintenance work [2]. Building maintenance includes processes and services to preserve, repair, protect and care of fabric and engineering 
services of the building. By delaying of maintenance work; decay, deterioration and failure of building play an important role to function at optimum level throughout their design life [3]. All buildings must be maintained throughout their lifespan. Less maintained building would have to compromise its durability and reliability considerations, which are very critical characteristics of a building [4]. The building maintenance program should be systematic and proactive to prevent the need for regular repairs. It should have sufficient staff and budget for proper maintenance [5].

Depending on its design, quality of materials and workmanship, function and location, building deterioration may take different rates and require different levels of attention. No building will ever be maintenance-free but the quality of the design and workmanship can minimize the level of maintenance required for it [6]. Buildings are intended to implement the main functions of a building to its optimal use. The buildings that cannot be maintained will be damaged and will cause failure in their life time. This damage is caused by human factors, such as lack of understanding and knowledge of workers on maintenance and repair work techniques [7].

Building maintenance is required once the building is complete. At the early stage, a defect occurs due to the design of the building. Throughout the construction process, all design changes are required and recommended by an architect shall be borne by the noble hand. Defects caused by negligence during construction will be borne by the contractor. Warranty period against defects of six or twelve months is the provisions of the construction contract. During this period, the contractor shall repair any defect found with its own cost. After that period, the building manager must provide more maintenance program with required resources. Furthermore, it is required to conform that the building is fully functional and producing gains in economic life [8].

Nowadays, it has become a great challenge for developing countries like Nepal to ensure that the condition and quality of each and every building is at the top so that their serviceability can be maintained and can fulfill their functional requirements [9]. It is obviously necessary to adopt a good building maintenance or protection method. Public buildings have sparked more awareness among the engineering community in the case of importance of good and systematic building maintenance [6].

\section{Theoretical Background}

Public building maintenance problems can be accessed by taking in-depth understanding of all aspects of the maintenance such as types, components, problems, their causes, effects and appropriate solutions.

\subsection{Types of Maintenance}

There are various types of maintenance. But the major types are grouped as planned and unplanned maintenance (Figure 1).

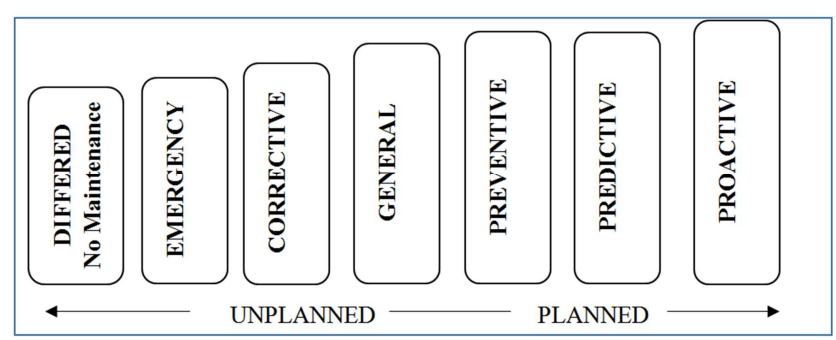

Figure 1. Continuum of Maintenance for Buildings.

Planned maintenance includes Preventive, Predictive and Proactive maintenance whereas unplanned maintenance includes General and Corrective maintenance. Types of maintenance under planned and unplanned maintenance are briefly described below.

Preventive Maintenance is a planned program of periodic inspections, adjustments, and replacements [10]. Preserving the assets like the buildings' roofing, plumbing, heating, ventilation, air conditioning, electrical systems, exteriors, and interiors is a primary objective behind preventive maintenance [11].

As the name implies, Predictive Maintenance involves the prediction of the failure before it occurs, identifying the root cause for those failures symptoms and eliminating those causes before they result in extensive damage [10].

Proactive Maintenance on the other hand is a preventive maintenance strategy that works to correct the root causes of the failure and avoid breakdowns caused by underlying equipment conditions. The purpose of proactive maintenance is to see failures as something that can be anticipated and eliminated before they develop. Creating a proactive maintenance helps organizations find hidden inefficiencies [12].

Maintenance work has also been categorized as 'predictable' and 'avoidable'. Predictable maintenance is regular periodic work that may be necessary to retain the performance characteristics of a product, as well as that required to replace or repair the product after it has achieved a useful lifespan. Avoidable maintenance is the work required to rectify failures caused by poor design, incorrect installation or the use of faulty materials [12].

With building services, minimal negligence can result in potential danger. 'Appropriate condition' could be interpreted as the maintenance of building in a state, which allows them to be used for the purpose for which they were provided for the minimum capital expenditure. The appropriate condition will be influenced by many factors, including the function of the building, its public image, or even national prestige. The prime aim of building maintenance should be to obtain good value for money spent on maintenance [10].

Another approach to maintenance classification has been made into three broad categories [13]:

1. Major repair or restoration: such as re-roofing or rebuilding defective walls and often incorporating an element of improvement.

2. Periodic maintenance: a typical example being annual contracts for decorations and the like. 
3. Routine or day-to-day maintenance: This is largely of the preventive type, such as checking rainwater gutters and servicing mechanical and electrical installations.

\subsection{Components of Maintenance}

There are many components of maintenance. Some of the components of maintenance have been described by the Seeley [14]. These are listed and briefly described hereunder.

\subsubsection{Servicing}

Servicing is essentially a clearing operation undertaken at regular intervals of varying frequency and is sometimes termed day-to-day maintenance. Daily sweeping of floors, monthly washing and cleaning of windows, regular painting for decoration and protection every four years are some examples of servicing. However, as more equipment that are sophisticated are introduced so more complicated service schedules become necessary. Servicing becomes necessary because of constant use of facilities, the effect of the weather and atmospheric conditions on the components of the building [14].

\subsubsection{Rectification}

Rectification work usually occurs fairly early in the life of a building; but it can also occur sometimes within the life span of the building. It arises from shortcoming in design, inherent fault in or unsuitability of component, damage of goods in transit or installation and incorrect assembly [14]. Rectification represents a fruitful point which is to reduce the costs of maintenance, because it is available. All that is necessary at any rate in theory is to ensure that components and materials are suitable for their purpose and are correctly installed. Rectification work could be reduced by the development and use of performance specifications and codes of installation [15]. Rectification is the response to inherent defects in design, construction or installation stages of the building process. This provides an opportunity to "trade off" current capital expenditure against future maintenance costs.

\subsubsection{Replacement}

Replacements occur at all costs in buildings. It is inevitable because service conditions cause materials to decay at different rates. Much replacement work stems not so much from physical breakdown of the materials or element as from deterioration of the appearance [14]. This is because the extent of exposure of materials to the vagaries of the weather varies, and the weather in specific locations also vary whilst the capacity of elements of buildings in withstanding changes and different intensities of the weather vary. This therefore becomes necessary as a result of material decay due to these differential rates of weather conditions. Physical breakdown of materials or elements as well as deterioration appearance may necessitate replacements.

However, this brings the problem of distinguishing between maintenance and improvement, which has not been resolved satisfactorily by many definitions. However, it is generally conceded that maintenance should include reasonable elements of improvement, for example, the replacement of worn out component with up-to-date version. Where the intention of work done to increase efficiency in the use of the building by adding facilities, which were not previously present, should be classified as improvement. Therefore, it is logical to extend the meaning of maintenance to cover some localized improvement [15].

\subsection{Building Maintenance Problems}

Building maintenance problems are commonly treated as a failure or shortcoming in the function of building, performance, statutory or user requirements and this may occur in its structure, fabric, services or other facilities [16]. The building defects mostly occur at the operational phase of building and maintaining that defect not only manifests itself but before and during the construction stage.

Defects in buildings are commonly classified as patent and latent defects [17]. Patent defects can be clearly recognized during inspection during the construction and the project's Defects Liability Period (DLP). Latent defects usually appear over the time when the building is occupied.

The most detective elements in architectural works are doors and finishes [18]. Plumbing installation, electrical system and air conditioning system tends to be most defective in mechanical works. There was a general dissatisfaction over the selection and procurement of some of the materials, equipment's and specifications and this contribute to operational problem when taking over the building.

Major maintenance problems in buildings are electrical problems $15 \%$, plumbing works $28 \%$, cracks $26 \%$, painting works $10 \%$, floor works $5 \%$, and lift maintenance $16 \%$ [19]. Furthermore main maintenance issues are sanitary problems, water leakages, lift stoppings, and dampness.

The common problems facing the operation and maintenance departments in Saudi Arabia can be categorized into three groups; management problems, human resource problems and technical problems [20]. There are fourteen obstacles that the operation and maintenance industry has been facing: The Top Management Problems (Poor Management of Maintenance Team, Procurement Management, Unqualified Maintenance Contractor, Government Regulations and Rules, Stakeholders Communications), The Human Resource Problem (Lack of Supervision from Maintenance Team, Lack of Engineers and Specialist, Training and Motivation, Unclear Job Description and Department Structure, Lack of Awareness), The Technical Problem (Lack of Maintenance Software Tool, Shortage of Spear parts, Failure of Preventive Maintenance).

A survey was conducted in the Jimma Town of Ethiopia targeting to find out causes of defect, factors affecting maintenance management and the maintenance management practices on low cost building. The study prevailed the following maintenance problems and ranked in terms of decreasing order of their weightage [21];

a) Leaking pipes; Leaking water that seeped out from behind walls, under concrete slabs and asphalt, 
basements, landscaping, water intrusion in roofs, irrigation systems, and radiant heat system. The most recurrent problems occur in sanitary appliances, sinks, showers and taps [22]. It was observed that the most frequent requests in relation to the hydro sanitary installations are referring to leaks in discharges and sinks as well as the need of tap change.

b) Peeling paint; peeling paint was critically found on the building facade, especially on the plastered walls, ceilings, beams and columns.

c) Cracking; cracks in wall were in various directions and varying in width from cracks to $5 \mathrm{~mm}$ or more. There were long and continuous cracks across the walls, beams, columns, ceilings and floors. Moreover, a diagonal crack was found at the corner of door where the crack tip was very thin with increased thickness at the initial point.

d) Damp; approximately $72 \%$ of the building had damp problems. The most common types of dampness are likely to be: Penetrating dampness, Rising Dampness, Leaks on Services. Dampness can arise from unintended water caused by leaking pipes, gutters and flashings. The leaking water penetrated into the wall, resulting in horrible water stains [23]. Under long term of dampness penetration and poor ventilation within the building, excessive moisture promoted the growth of mold or fungi on the surface of wall [24].

e) Sagging or deformation (roof); the roof defects found were the blocked gutters, leaking downpipes, leaking roofs, missing roof tiles, slipping roof tiles and also defective soffit and fascia board.

f) Broken tiles; the major problems found in the inspected schools were cracked, broken and loose tiles.

g) Faulty electric system; major problems on lamps and light fixtures/sockets/circuit breakers/switches/wiring, lack of energy, power failure, adequacy of electrical installations.

h) Mold or Fungi; the growth of mold or fungi are ordinary consequences caused by excessive dampness. Mold and fungi will grow when they gain enough moisture and nutrients [24].

i) Timber decay.

j) Termite.

According to study conducted in Brazil, the results showed that the 86 percent maintenance problems were related to the refrigeration, electrical and hydro sanitary installations, which represent 55 percent of the total problems [22]. Remaining were door/window glass, wood works, networks and communications, elevators, cladding, lining, masonry, floor, structure and foundation related problems.

Common types of building defects include: structural defects resulting in cracks or collapse, defective or faulty electrical wiring or lighting, defective or faulty plumbing, inadequate drainage systems, faulty ventilation, cooling or heating systems, insufficient insulation or sound proofing and also inadequate fire protection suppression systems [25]. Plus, dry rot, wood rot, mold, fungus, or termite or vermin infestation may also be the result of a building defect.

From time to time, the maintenance works become more challenging due to construction of new building and also aging of the existing buildings. Maintenance department in the various universities are facing common problems mostly to maintain functionality of buildings. First is the human resource problem which includes skill and experiences of employees. Quality performance problem is next one and it depends mainly on adequate tools, equipment and materials. Lastly, maintenance plan, strategy, budget allocation and so on can be categorized in management problem [26].

\subsection{Causes of Building Maintenance Problems}

Building maintenance is required only quite later after the building is completely handed over. At the early stage, defects may occur due to the design of the building. Throughout the construction process, the design changes, negligence in construction and supervision and so on become the sources of maintenance problems. Normally six or twelve months warranty period against defects will be set as provision of the construction contract. During this period, the contractor shall repair any defect, if found, with its own cost. After that period ends, the building manager should be responsible to provide more maintenance program. It is expected to respond that the building is fully functional and producing gains in economic life [8].

Poor maintenance work is due to insufficient supervision by the maintenance organization. The researcher pointed out that the inadequate training to the employees can leads to poor building maintenance. Specification of unsuitable materials is always a problem in maintenance works [27]. The quality of the buildings depends on available resources that relevant with user's requirements [28]. Appropriate material is available but that is not in sufficient quantity. It can still prevent employees from doing maintenance works [27].

Poor specifications, selection of materials, workmanship and supervision are the common causes of building defects [16]. Furthermore, poor design decision is identified as the most significant contributor to the defects. The causes of building maintenance problems with in decreasing order as Design causes, Workmanship causes, Materials causes and Lack of Protection causes [18]. The main problem of insufficient funds in maintenance is due to the bad management plan and policy [4].

Poor maintenance of public buildings and infrastructure can lead to accidents and injuries [29]. Buildings and facilities that are not properly maintained can cause discomfort and lead to accidents and injury to people. The consequences of poor maintenance and causes of the incident like bad service problem, improper work implementation, poor management, poor maintenance culture and lack of work ethic among those involved in maintenance [30].

The causes of pipe leaking and faulty electric system were due to poor workmanship and use of low quality materials [21]. These components were consistently exposed to sunlight, rain, wind and dampness, resulting in peeling paint. 
The causes of blocked gutters were the growth of plants and accumulation of leaves and debris. As the result, the rainwater will overflow when there was a heavy rain. However, it was also discovered that gutters were not constructed along during the construction stage at some of the buildings. Heavy objects dropped on the tiles would crack and break the tiles. In brief, this defect was caused by vandalism, impact damage, improper maintenance and poor materials. Generally, the major contributing causes of defects were; Weakness in design, Poor workmanship, Low quality material and Lack of awareness.

Furthermore, the contributing factors for causing building defects were grouped in following sub-headings and ranked in terms of decreasing order of their weightage [21];

a) Lack of sufficient budget.

b) Unclear material specifications.

c) Weak construction supervision.

d) Lack of preventive maintenance (maintenance culture).

e) Faulty design and poor workmanship.

f) Lack of building maintenance standard and policy.

g) Client's poor attitude to maintenance.

h) Incorrect selection of building material component and system.

i) Lack of understanding the importance of maintenance work.

A building defect may also include damage caused by land movement or earth settlement. Proving a building defect commonly requires the hiring and testimony of a highly trained and experienced expert. An expert, such as an engineer or an architect, is the one who will be able to determine the construction problem involved due to the result of improper design, material or workmanship.

One of the major causes to create maintenance problems is faulty design and accepting the same by the builders, which shows the ignorance of its impact on building stability and strength. Poor or faulty construction, speedy completion of work, inexperienced workmanship and lack of motivation play vital role for maintenance defects. The quality of work is affected by poor construction administration by neglecting maintenance issues at the time of design and construction [31].

Some of the root causes of building defects may easily be found out and some might take serious inspection by related experts. Any single evidence of origin of building defects may not be enough for making conclusions. Possible root causes should be examined from different angles [32]. Building defects can grounds range of building problems. Determining the origin of the deficiency will depend on which areas have been exaggerated. Defects in the foundation, floor or wall can be the direct result of soil issues, water issues or even workmanship issues. If an individual is noticing problems with foundation part, that may be caused by water or soil [33].

The major factors causing the building defects and failures are Construction Materials, Faulty Construction, Corruption, Lack of Supervision, Faulty Design, Climatic Condition, Lack of Maintenance, Building Type and Change in Use,
Location of Building [34]. Poor maintenance of public buildings is the result of lack of maintenance culture, age of building, apathy and ignorance of maintenance responsibility, poor construction work, inadequacy of funds but high cost of maintenance and capacity of maintenance personnel.

There is also the problem of over-centralization of maintenance decisions. Maintenance decisions and building management are taken at the management level at the headquarters and the regional office of the institutions surveyed. The channels through which decisions are brought to the local level are in most cases, lengthy process causing the delay in release of funds for maintenance. These bureaucratic processes also affect the reporting of maintenance problems by personnel, since some occupants have failed to report maintenance problems citing this bureaucratic process as a hindrance. Lack of communication between maintenance managers and architect or design engineers will lead to improper output [19].

Various researchers conducted their study on factors affecting the building maintenance management and presented their findings. Those factors can be known as causes of building maintenance problems.

According to the study conducted about factors affecting building maintenance of public buildings in Penang, Malaysia; lack of preventive maintenance, insufficient funds to maintain the building, lack of building maintenance standard, non-availability of replacement part and components and not responded to maintenance request are the major factors affecting maintenance [35]. Based on these results there should be an increased demand for the effectiveness and efficiency from the maintenance department staff.

The most significant factors affecting residential building maintenance in Nigeria based on the insight of users were lack of preventive maintenance, faulty workmanship, design resolution factor and the use of substandard materials. These factors are a real threat to the structural and functional state of the building and consequently, this would lead to rapid deterioration. The least significant factors were lack of communication between maintenance contractors and clients, lack of understanding the benefits of maintenance, unavailability of replacement parts and components, and technological change [36].

The factors affecting the housing maintenance in public and private housing facilities in Nigeria were: design and proper workmanship, material specifications, detailing of working drawings, construction supervision, cash flow analysis, environmental factors, users activities, shifting values and modernizations, inadequate waste management plan, accidents, solar radiation, gradual depreciation, aging, wear and tear, preservation of historical background, value of buildings, alterations and modifications, inadequate housing stock, low quality of original construction and social factors [37]. The results were design and proper workmanship, material specifications, construction supervision and detailing of working drawings were the most significant factors affecting housing maintenance. 
Factors affecting building maintenance in government residential estates in Akure, Nigeria were studied by [38]. Their unit of analysis targeted the residents of three different government owned states. The factors which they considered in their study were: lack of funds, lack of maintenance culture, indiscipline/ignorance, bad economy, death of owner of building, quality of building materials, lack of skilled maintenance personnel, remoteness of the building, absence of the owner, family quarrel. Their results showed that lack of funds was the most significant factor affecting building maintenance, since finance is a major factor that affects maintenance work because it dictates the amount of repairs that could be conducted.

The challenges of some public and private buildings maintenance in Nigeria were explored by [11]. They recognized the defects, their causes and suggested some solutions. Their unit of analysis targeted the building industry professionals. Their results showed that the use of untested or inferior materials such as cement, aggregate and water was the most significant factor causing defects, as these materials are being used in the construction and absolutely they will result in a poor building condition which will lead to more maintenance work.

Factors affecting housing maintenance cost in Scotland were recognized by [39]. Their unit of analysis targeted local authority and housing associations. They categorized the factors into five groups: building characteristics, tenant factors, maintenance factors, political factors, and other factors. Their results showed that improper use of the property and high expectations of tenants were the most significant factors affecting housing maintenance.

Others studied the factors affecting housing maintenance cost in Malaysia. Their unit of analysis targeted building managers or supervisors, maintenance management staff. They categorized the factors based on the previous study of El-Haram and Horner. Their results showed that expectation of tenants, building materials, building services, building age and failure to execute maintenance at the right time were the most significant factors affecting housing maintenance [40].

\subsection{Effects of Building Maintenance Problems}

Patent and latent defects in buildings are serious issues and failure to address them would most likely contribute to additional rectification cost, hamper the smooth operation of the building and reduce its service life [17]. A building defect is a physical occurrence that causes building to be less valuable, effective, healthy, and something that cases weakness. Defects create hazards leading to series or fatal injuries. Most defects can at their early stages should discovered through visible or detectable symptoms. If not promptly rectified, minor defects can develop into serious ones causing failure or sudden collapse, endangering lives and becoming more costly to rectify.

Many security problems can occur to the occupants if the maintenance works by maintenance organization is not completed or takes a long time to respond [27]. Buildings and facilities that are not properly maintained can cause discomfort and lead to accidents and injury to people [29].

The cracks in plaster and other finishing affected the appearance of the structure and did not pose any safety concern. Defective tiles can further affect the visual appearance of floors and walls [21].

Defective building construction not only contributes to the final cost of the product but also to the cost of maintenance which can be substantial. Defective construction may lead to complete failure of structure. The construction industry all around the world is getting modern, advance and growing day by day with the help of information technology age. Housing Project represents a significant part of our society. Construction defect has become a global issue faced by practitioners and researchers around the world. Defects can affect success of construction project significantly. More specifically, it has major impact on maintenance cost, time, productivity, sustainability aspects and on customers' satisfaction as well [41].

Negative effect of building maintenance problems may arise towards cost, duration and resources of project. Failures and defects can cause unnecessary expenditure and delays. They are also generating controversies among parties involved. Furthermore, if this situation is left unanswered and untreated, it will lead to more serious problems in the future upcoming construction projects [34]. Failure to undertake maintenance of a building will ultimately result in reducing the life span of the building and consequently result in demolition. Maintenance of the building will however ensure that the building is restored to its initial status and also increase the life span of the building.

The building that cannot be maintained will be damaged and will cause failure in their life time. Thus, functionality of building will be lost and there will be the huge expenditure for new construction. Timely addressing of maintenance problems can minimize maintenance cost and save investment for replacement construction [7]. Furthermore, there will be the serious issues regarding the users and property safety due to the improper handling of maintenance problems.

\subsection{Maintenance Policy, Practice, Financial and Managerial Status of the Maintenance Department}

The maintenance department in an organization which is managed by a maintenance manager, is significantly decisive one. The maintenance manager is responsible for the planning and control of maintenance operations. In a small firm, the functions may be undertaken by a staff member in addition to his/her other duties, while in a larger firm there would be a separate group of people solely responsible for maintenance. Basic functions of the maintenance department are: Advisory, Organizational, Control and Miscellaneous. A maintenance organization can be considered as being made up of following three necessary and interdependent components [42];

a) Resources: men, materials, tools, budget.

b) Administration: a hierarchy of authority and responsibility for deciding what, when and how work 
should be carried out.

c) Work Planning and Control System: a mechanism for planning and scheduling the work and feeding back the information that is needed for correctly directing the maintenance effort towards defined objective.

Maintenance management is connected with the condition of the building elements and services so that it meets the standards required to be performed as desired [43]. According to researchers, maintenance management covers many functions that can be considered as an efficient use of resources to allow the techniques and facilities to operate as the consumer expectations. Maintenance management objective is to discover the correct combination of building maintenance methods by choosing the excellent maintenance technique for every element in the building [44]. Method of maintenance management undertaken should be constantly reviewed to ensure high quality services [43]. Many negative comments in public exposed that university buildings in Malaysia are not performing well [4]. Thus, maintenance management in the university depends on the methods carried out as well as supervision by the university sector to achieve better outcomes.

The Chartered Institute of Building has listed some steps to help in improving maintenance management practices as follows [45]:

a) Having a well trained and experienced maintenance staff.

b) Using maintenance programs which include the standards and response time.

c) Keeping all records from sites, renewal dates, service agreements, buildings, redecoration, engineering service and costs.

d) Using the best methods to spread information to help in reducing cost and failures that caused them.

Meeting the requirements of the building users and satisfying them and maintaining all building facilities are the result of effective maintenance practices [45].

The practices of maintenance management in public hospitals in the Gaza Strip found that the application of corrective maintenance was done in most hospitals, while preventive maintenance is applied in few hospitals [46]. They also found that there were variances in responding to maintenance requests because of the unqualified maintenance staff and the lack of spare parts. Furthermore, most of the hospitals did not have a maintenance program. They stated that it is the responsibility of the maintenance department to preserve all the facilities and elements of the building, and to make sure that the supporting systems are operating effectively. Finally, they recommended that the maintenance staff should have the required experience and they should be well trained to do their jobs effectively. Besides, all hospitals should have an inventory for all spare parts to respond immediately to any maintenance request.

Various researches were concerned on to "recognize the most maintenance practices of building maintenance", "weaknesses of the practices of the building maintenance that have been carried out" as well as "improvement strategy for a better practice of building maintenance" in public buildings. The researchers concluded their findings in this regards as;

A. Types of maintenance practices used

Corrective maintenance practices is the one of the mostly used practices of building maintenance following by condition-based and schedule maintenance. Furthermore major activities of maintenance practices were divided into maintenance management, employee's expertise and materials quality and availability [47].

\section{$B$. Weakness on maintenance practices}

There was an inappropriate plan and policy of maintenance management in universities which led to the poor maintenance management. Insufficient of comprehensive maintenance management is due to incompetency of employees in making decision procedure to solve defects problems [48].

Maintenance managers of maintenance management were not capable and competent to take decision. Without expertise, it leads to ineffectiveness and incompetency of employees' workmanship in maintaining the buildings [49]. Moreover, one of the complications in maintaining the building is funding [27].

Employees at the universities are specialized in certain skills and not experts in all areas. Without expertise, it leads to ineffectiveness and incompetency of employees' workmanship in maintaining the buildings [49]. Lack of training among employees also leads to poor maintenance in hostels. Inadequate training to the employees contributes to the poor maintenance practices [27].

There was lack of proper training programs and insufficient supervisors who were responsible to manage the training schedule and maintenance course to the employees at the university [48].

Low and medium qualities of materials were used in students' hostel buildings. Poor construction work seems to begin with the low quality materials [27].

Required materials were always out of stock and some materials were difficult to get in a short period of time. Maintenance organizations with insufficient materials face difficulties for managing a facility to original function [50].

\section{Improvements on maintenance practices}

Employees have to be competent and skillful to create a good plan and policy of maintenance management. Employees' competencies will ensure the quality and value of maintenance management [48].

Providing adequate training to employees can enhance employees' performance and productivity. The maintenance works that has been conducted need to be revised constantly [50]. Supervisor also has to manage the maintenance schedule to ensure the method of maintenance management undertaken is constantly revised. Long term maintenance plan need to be reviewed and revised after every inspection [6].

Providing adequate and regular training on maintenance courses to employees can improve employees' expertise. Providing training is significant for better building 
maintenance [27]. On the other hand, supervisors must be employed to monitor the employees' works and their training schedule. Supervisor has to ensure that the employees participate in training programs regularly.

The organization must ensure that their organization had sufficient staff to deliver comprehensive training to employees [27]. Universities should invest some money on training their employees [4].

High quality and durable materials are very important to be used in carrying out building maintenance in hostels. Good quality and durable materials are used to prolong its life span as well as to reduce the rate of deterioration [27]. For improvements, materials should follow the standards and specifications. This shows that, employees must follow the materials schedule as specified for better understanding of materials as well as estimate their cost [43].

Supervisors should monitor and ensure the necessary materials are always available. There has to be guidelines for the allocation of maintenance resources [50]. There should be a specific place to keep and store materials. Schedule of materials is important to keep track of which materials are out of stock. The schedule provides a normal life expectancy for materials available [51].

\subsection{Solutions of Maintenance Problems}

Nowadays, it has become a great challenge for developing countries to ensure that all the condition and qualities of all the buildings are at the top, so that their serviceability could be maintained and can fulfil their functional requirements [9]. It is obviously necessary to adopt a good protection method or can be said as a building maintenance. Building maintenance is the sector closely related to the building construction industry. Building maintenance has been practically adopted after the completion of a construction project. In general, building maintenance is any practice that could assist in extending the lifespan of a building so that it could fulfil its function [52].

In order to execute maintenance activities efficiently, a suitable maintenance plan should be set [40]. Maintenance management is responsible for using tools and methods to improve the efficiency and to reduce the effects of unplanned stoppages and to reduce costs [53].

A systemic building maintenance management model improves the functional performance of a building by integrating perspective and activities that are traditionally separated. Traditionally, the criteria of user's value systems are not incorporated into maintenance management systems. However, buildings are only valuable if they continue to provide the intended services adequately to the users. A failure of this will render the existence of the building insignificant or useless [4].

The main problem of insufficient funds in maintenance is due to the bad management plan and policy [6]. Maintenance management should be capable to manage all resources required for good performance of the building. Therefore, the technique of maintenance management that is carried out must continuously be revised to encourage the high quality of services [43]. Besides that, the author further stated that, maintenance work was not only necessary to correct any defects but also to be recorded.

The generated ideas using brainstorming technique should be implemented during the design stage or initial stage of construction, so there is chance of decreasing the effects of maintenance problems of building from the design stage. If the maintenance problems are reduced, automatically the maintenance cost of the building will also reduce [19]. Furthermore, some suggested points by the researcher as listed below are applicable to reduce the maintenance problem in cost prospective view;

1. Take precautions from the designing stage.

2. Implement value management techniques.

3. Use only the quality materials.

4. Implement the new technology giving proper training to the employees for the effective utilization.

5. Apply adequate supervision while construction work is going on.

6. Procure skilled labor.

7. Use effective maintenance management team to control over all maintenance issues during the design and initial stage of construction.

To improve maintenance performance of public building, concern should be given to significant preventive maintenance characteristics at the time of planning and implementing maintenance activities. Those characteristics for consideration are skill and knowledge of maintenance labor, quality of spare parts and materials, length of predetermined maintenance interval, skill and knowledge of maintenance manager, capability to adopt maintenance equipment and technique, budget allocation for acquisition of maintenance data, reliability of maintenance data as well as frequency of monitoring and inspection [54]. In order to improve the effectiveness of maintenance strategy and the maintenance performance, the researcher recommends practice and provision of communication platform such as meeting and customer satisfaction survey that involves all the key participants from clients to customers.

It is important to identify the common problem being faced by the maintenance department. Similarly, it is important to examine the current status of the maintenance department like; organization structure, standard operation procedure (SOP) in maintenance works, mission and vision, objective of department and also the scope of work. Only after identification of problems it is reasonable to propose any suitable approach that could be implemented to overcome the problem faced by the maintenance department [26]. There should be an increased demand for the effectiveness and efficiency from the maintenance department staff [35].

If the life-cycle of a building increased the age of the building should be increased so we should particularly go for building maintenance like repairs, plumbing, sanitation, painting works etc. Strategic planning and implementation of the aspect determine the effectiveness of the output [19]. 
The maintenance problems associated with building can be studied by analyzing the building as a hole in small components of facilities like; substructure, superstructure, finishes, fittings, internal or external services. It is important to find out maintenance problem in the construction industry and understanding the possible causes of defects at design stage (eg. fundamental errors in concept, site selection and site development errors, programming deficiencies, design errors), at construction stage (e.g. construction errors, materials deficiencies) and at service stage (e.g. operational errors) guides for effective maintenance performance [55].

Maintenance experts should be involved in the planning stage and the design is to be reviewed before starting of construction work. Similarly, it is important to employ maintenance professionals at every stage of construction works [31].

Maintenance inputs during the design phase for the ease of maintenance to decrease design defects is the beneficial solution [40]. Thus, the involvement of construction professionals in the design phase could help avoiding maintenance problems. Input from qualified and competent construction industry professionals is one way to decrease the defects occurring and to achieve quality of maintenance processes [38]. Besides this, a relationship between construction supervision and material specifications is needed [37].

Assessment on the practices of maintenance management in government office buildings found the maintenance practices is one of the most important issues that should be taken into consideration [56]. Besides, maintenance should be carried out efficiently and that would result in improving these practices. Maintenance department should be responsible for carrying out all maintenance works and taking all complaints from all users seriously. Furthermore, the maintenance program should be reviewed to check what maintenance problems have been solved and how to solve all remaining problems.

Appropriate maintenance management model would be helpful to overcome the management issues like: budget allocation, diversity of maintenance problems, lack of past maintenance data, responsibility ignorance tendency of deputed personals, modern maintenance technology, availability of skilled human resources, safety and environmental concern [2].

Building Manual consisting of $\mathrm{O} \& \mathrm{M}$ manual, as built drawing, health and safety document, standard and emergency operating procedure and more is to be prepared and followed for effective and efficient maintenance management process [24]. Furthermore, the building User Guide assists the occupants in making best use of the design features, services and systems of building thus ensuring a safe and healthy work environment. It contributes to the effective and efficient operation and management of building. It provides the end users or occupants of the building with the simple, easy and quick guide to the everyday function of the building.

The following points to be strictly followed for well- maintained buildings [23];

1. Introduce effective maintenance performance evaluation system through authorized maintenance department.

2. Perform periodic condition assessment/surveys from which maintenance workload and prioritization of maintenance work is determined.

3. Apply planned preventive maintenance practice as a high priority rather than emergency or condition based maintenance.

4. Maintenance department should incorporate preventive maintenance tasks into a work-order system and keep systematic maintenance records, either by computer or manually. They should evaluate the preventive maintenance program to improve it over time.

5. Develop building maintenance culture, and

6. Manage adequate building maintenance fund.

The most significant factors of maintenance problems are the use of defective construction materials, poor supervision, non-compliance with specifications and poor quality control on site. Therefore, it is imperative for design and construction professionals to ensure the use of good quality materials and comply with specifications through adequate supervision to trim the menace of maintenance during operation of buildings [57].

\section{Conclusions}

Public buildings of any nation are too valuable assets and maintaining them at regular functional state is becoming challenging job for developing countries like Nepal. Decay, deterioration and failure of the fabric and finishing of a building due to negligence of maintenance have harmful effects on the contents and occupants. Public building maintenance work consists of combination of all technical, administrative and managerial actions with effective and efficient program Building elemental and service related maintenance problems such as plumbing, electrical, sanitation, finishing, cracks, peeling of paint, dampness and more seem to be the most common. Causes of maintenance problems can be grouped as managerial, technical, building user related and natural causes. There are major causes such as design defects, inadequate contractor and construction supervision, use of low-quality materials and workmanship, unavailability of qualified manpower and quality materials, poor maintenance management, less maintenance fund but high and unexpected cost, age of building, natural disaster and earth settlement and so on. Lack of proper maintenance department, programs, plan and policy are the critical issues of improvement by public institutions. Failure to address serious issues like patent and latent defects in buildings would contribute to additional rectification cost, hamper the smooth operation of the building and reduce its service life. Buildings and facilities that are not properly maintained can cause discomfort and lead to accidents and injury to the users. 


\section{References}

[1] Peter Brown \& Mike Sodalini (2005), Article; Evolution of maintenance. (C) 2005-2020 Lifetime Reliability Solutions, World Class Reliability. Retrieved from http://www.lifetimereliability.com/freearticles/maintenance_management/Evoluti on_of_Maintenance_Practices.pdf.

[2] Crespo Márquez, Adolfo (2007), The Maintenance Management Framework, Models and Methods for Complex Systems Maintenance, (C) Springer.

[3] Olanrewaju A. (2010), Case for alternative approach to building maintenance management of public universities. Journal of Building Appraisal 5: 201-212.

[4] Lateef O. A. A, Khamidi M. F, Idrus A. (2011); Behavior Issues in Maintenance of University Buildings; Journal of Retail \& Leisure Property (2011) 9, 415-4 28. doi: 10.1057/rlp.2011.5.

[5] Bastidas Pedro (1998); MAINTENANCE MANUAL FOR SCHOOL BUILDINGS IN THE CARIBBEAN; Report presented for USAID-OAS Caribbean Disaster Mitigation Project on March 1998.

[6] Ahmad Suffian (2013); Some Common Maintenance Problems and Building Defects: Our Experiences; Article presented in The 2nd International Conference on Rehabilitation and Maintenance in Civil Engineering, Social Security Organization (SOCSO), Malaysia.

[7] Latief, Yusuf \& Machfudiyanto, Rossy Armyn \& Soepandji, Budi \& Khairina, \& Aldesty, Riany. (2018). The development of quality management systems in maintenance and monitoring the process of risk-based repair work in government buildings. MATEC Web of Conferences. 195. 06005. 10.1051/matecconf/201819506005.

[8] Mohd Nasrun Mohd Nawi, Faizal Baharum, Siti Halipah Ibrahim and Salman Riazi Mehdi Riazi (2017) A Review Study of Maintenance and Management Issues in Malaysian Commercial Building towards Sustainable Future Practice.

[9] Hani Muftah (2010); Faulty Design and Construction Factors In Building Maintenance Master Thesis (Johor: Universiti Tun Hussein Onn Malaysia).

[10] Ogunmakinde, O. E., Akinola, A. A., and Siyanbola, A. B. (2013) 'Analysis of the factors affecting building maintenance in government residential estates in Akure, Ondo State, Nigeria', Journal of Environmental Sciences and Resources Management, Vol. 5 No. 2, pp. 89-103.

[11] Dictionary of Military and Associated Terms, US Department of Defense, 2005.

[12] Mydin, M. A. (2015) 'Implementation of Effective Maintenance Management in Building Works', Journal of Industrial Engineering Research, Vol. 1 No. 4, pp. 17-22.

[13] Shao, Allan. T (1999), Marketing Research: An Aid to Decision Making (www.sbaer.uca.edn).

[14] Seeley, I. H. (1987); Building Maintenance'. The Macmillan Press. London, U.K.

[15] Lee, R. D. (1987) Building Maintenance Management, Oxford,
U.K.

[16] A. Mills, P. E. D. Love and P. Williams,(2009). "Defects cost in residential construction," Journal of Construction Engineering and Management, vol. 135, Jan. 2009, pp. 12-16, doi: 10.1061/(ASCE)0733-9364(2009)135: 1 (12).

[17] B. Rhodes and JJ Smallwood, (2002). "Defects and rework in South African construction projects," Proc. Construction and Building Research Conference (COBRA 2002), RICS, Dept. 2002, pp. 1-15, ISBN 1-84233-074-8.

[18] Haryati Mohd Isa (2011). Learning from Defects in Design and Build Hospital Projects in Malaysia. International Conference on Social Science and Humanity IPEDR vol. 5 (2011) (C) (2011) IACSIT Press, Singapore.

[19] P. Bhargava Reddy, B. S. S. Ratnamala Reddy and SS. Asadi (2018), Evaluation of Maintenance Management in Construction to Reduce the Maintenance Cost, International Journal of Mechanical Engineering and Technology 9 (3), $2018 . \quad$ pp. 367-374. http://www.iaeme.com/IJMET/issues.asp?JType=IJMET\&VT ype $=9 \&$ IType $=3$.

[20] Ayman Alshehri, Ibrahim Motawa \& Stephen Ogunlana (2015); The Common Problems Facing the Building Maintenance Departments, International Journal of Innovation, Management and Technology, Vol. 6, No. 3, June 2015, Retrieved from http://www.ijimt.org/vol6/608-W3006.pdf.

[21] Arif Awol, Dr. Ing. Tamene Adugna, Alemu Mosisa, (2016). Assessment on causes of defect and the maintenance management practices on low cost building; (A case study of Jimma Town Condominium). International Journal of Engineering and Technical Research (IJETR) ISSN: 2321-0869 (O) 2454-4698 (P), Volume-5, Issue-3, July 2016.

[22] Alves Tenório de Morais, G. and Casado Lordsleem Júnior, A. (2019), "Building maintenance management activities in a public institution", Engineering, Construction and Architectural Management, Vol. 26 No. 1, pp. 85-103. https://doi.org/10.1108/ECAM-01-2018-0024.

[23] Elhag $\mathrm{T}$ and Boussabaine, Afranie (1999). Evaluation of Construction Costs and Time Attributes". Proceedings of the 15 th ARCOM Conference. Vol. 2, 2, 473-480, (pp. 15-21). Liverpool John Moores University.

[24] Jo Harris, Allan Wilson and Salim Dermanchi, (2011), Building Manual and Building User Guide, (C) BSRIA BG 26/2011, Retrieved from www.bsria.co.uk.

[25] California Civil Code 896.

[26] Mohd Norazam Yasin et al (2017); The most common problem facing by the maintenance department: A case Study between Universiti Tun Hussein Onn Malaysia (UTHM) and Universiti Teknologi Malaysia (UTM); IOP Conference Series: Materials Science and Engineering, Volume 271-012047, conference 1, Retrieve from https://doi.org/10.1088/1757899X/271/1/012047.

[27] Cobbinah, P. J., (2010). Maintenance of building of public institutions in Ghana. Case study of selected institutions in the Ashanti region of Ghana. Unpublished master's thesis, Kwame Nkrumah University of Science and Technology, Kumasi. 
[28] Idrus, A., Khamidi. M. F., \& Abdul Lateef, O. A. (2009). Value based maintenance management model for university buildings in Malaysia-a critical review. Journal of Sustainable Development, 2 (3), 127-133. Retrieved from http://www.ccsenet.org/journal/index.php/jsd/article/view/424 $6 / 3696$ retrieved from http://eprints.uthm.edu.my/3497/1/MGT086.pdf.

[29] Sui Pheng Low (2001). Improving maintenance and reducing building defects through ISO 9000. Journal of Quality in Maintenance Engineering. 2001 Mar 1; 7 (1): 6-24.

[30] Zawawi EM (2009). Personnel characteristics of maintenance practice: a case of high-rise office buildings in Malaysia. Journal of Sustainable Development. 2009 Feb 18; 2 (1): 111.

[31] Okuntade, Tope. (2014). Effects Of Faulty Construction On Building Maintenance. INTERNATIONAL JOURNAL OF TECHNOLOGY ENHANCEMENTS AND EMERGING ENGINEERING RESEARCH. 2. 73-79.

[32] Abdul Hakim bin Mohammed, (2002), Teknologi Penyenggaraan Bangunan, Selangor.

[33] Pambo Fernandez, (1999), S. Factors influencing salt-induced weathering of building sandstone, Phd Diss. The Robert Gardon University.

[34] Ahzahar, N. \& Karim, N. A. \& Hassan, Siti \& Eman, J. (2011) A Study of Contribution Factors to Building Failures and Defects in Construction Industry. Procedia Engineering. 20. 249-255. 10.1016/j.proeng.2011.11.162.

[35] Talib, R., Ahmad, A., Zakaria, N., and Sulieman, M. (2014) 'Assessment of Factors Affecting Building Maintenance and Defects of Public Buildings in Penang, Malaysia', Architecture Research, Vol. 4 No. 2, pp. 48-53.

[36] Baba, W. and Buba, V. (2013) 'Evaluation of Factors Affecting Residential Building Maintenance in Nigeria: Users' Perspective', Civil and Environmental Research, Vol. 3 No. 8, pp. 2224-5790.

[37] Olayinka, A. and Owolabi, O. (2015) 'Evaluation of the factors affecting housing maintenance and its probable solutions', International Journal of Latest Research in Engineering and Technology, Vol. 1 No. 4, pp. 59-64.

[38] Olanrewaju, S. and Anifowose, O. (2015) 'The challenges of building maintenance in nigeria: (A case study of Ekiti State)', European Journal of Educational and Development Psychology, Vol. 3 No. 2, pp. 30-39.

[39] El-Haram, M. and Horner, M. (2002) 'Factors affecting housing maintenance cost', Journal of Quality in Maintenance Engineering, Vol. 8 No. 2, pp. 115-123.

[40] Ali, A. S., Kamaruzzaman, S. N., Sulaiman, R., and Peng, Y. (2010) 'Factors affecting housing maintenance cost in Malaysia', Journal of Facilities Management, Vol. 8 No. 4, pp. 285-298.

[41] Neha Bagdiya, Shruti Wadalkar, (2015), Defects and PostConstruction Defects Effect in Residential Building, INTERNATIONAL JOURNAL OF ENGINEERING RESEARCH \& TECHNOLOGY (IJERT) Volume 04, Issue 02 (February 2015), http://dx.doi.org/10.17577/IJERTV4IS020932.

[42] Dr. J. C. Okafor and Dr. I. A. Akeredolu (2017). COURSE GUIDE. HCM 234: FACILITY MAINTENANCE
MANAGEMENT, School of Management Sciences, National Open University of Nigeria. Retrieved from https://nou.edu.ng/sites/default/files/201703/HCM\%20234\%20FACILITY\%20MAI.

[43] Zulkarnain, S. H., Zawawi. E. M. A., Rahman, M. Y. A., \& Mustafa, N. K. F., (2011). A review of critical success factor in building maintenance management practice for university sector. World Academy of Science, Engineering and Technology, 5, 187-191. Retrieved from http://waset.org/publications/14040/a-review-of-criticalsuccess-factor-in-building maintenance-management-practicefor-university-sector.

[44] Al-Khatam, J. A. (2003). Building maintenance cost. Unpublished master dissertation. King Fahd University of Petroleum and Minerals, Dhahran, Saudi Arabia.

[45] Fakhrudin, I., Suleiman, M., and Talib, R. (2011) 'The need to implement Malaysia's Building and Common Property Act 2007 (Act 663) in building maintenance management', Journal of Facilities Management, Vol. 9 No. 3, pp. 170-180.

[46] Enshassi, A., El Shorafa, F., and Alkilani, S. (2015) 'Assessment of Operational Maintenance in Public Hospitals Buildings in the Gaza Strip', International Journal of Sustainable Construction Engineering \& Technology, Vol. 6 No. 1, pp. 29-43.

[47] Nur Afifah Sanusi (2019), A STUDY ON THE BUILDING MAINTENANCE PRACTICES IN STUDENTS' HOSTELS AT PUBLIC UNIVERSITIES, Journal of social science and humanities, University of Malaysia, Vol. 16. No. 3 (1-17), ISSN: $1823-884 \mathrm{x} \quad$ Retrieved from http://ejournal.ukm.my/ebangi/article/view/31409.

[48] Ismail, Z., \& Kasim, N. (2013, December). Maintenance management practices for building maintenance: Case studies. Paper presented at the 2nd International Conference on Technology Management, Business and Entrepreneurship Mahkota, Hotel Melaka Malaysia. Retrieved from http://eprints.uthm.edu.my/5126/1/Maintenance_Management _Practices_for_Building.

[49] Rahman, M. A. A. (2007). A study on the building maintenance management-case study: Mahallah Uthman Ibn Affan (IIUM male student residential college). Degree dissertation. International Islamic University Malaysia, Gombak.

[50] Lee, H. H. L., \& Scott, D. (2008). Overview of maintenance strategy, acceptable maintenance standard and resources from a building maintenance operation perspective, 4 (4), 269-278. Retrieved from http:/www.palgravejournals.com/jba/journal/v4/n4/pdf/jba200846a.pdf.

[51] NSW Heritage Office. (2004). Preparing a maintenance plan. Retrieved from https://www.environment.nsw.gov.au/resources/heritagebranch /heritage/maintenance11 pre paringplan.pdf.

[52] Barrie Chanter \& Peter Swallow (2007); Building Maintenance Management Second Edition (Oxford, UK: Blackwell Publishing Ltd).

[53] Oliveira, M., Lopes, I., Iaeng, M., and Figueiredo, D. (2014) 'Maintenance Management Practices of Companies of the Industrial Pole of Manaus' Proceedings of the World Congress on Engineering and Computer Science, Lecture Notes in Engineering and Computer Science, Vol. 2214 No. 1, pp. 1016-1022. 
[54] Au-Yong, C. P., Ali, A. S. and Ahmad, F. (2014) Preventive Maintenance Characteristics towards Optimal Maintenance Performance: A Case Study of Office Buildings. World Journal of Engineering and Technology, 2, 1-6. http://dx.doi.org/10.4236/wjet.2014.23B001.

[55] Ir. Abdul A. Abas (2010), Building Maintenance; civil and structural engineering approach, A report presented to University Technology Mara.
[56] Husaini, A. and Tabassi, A. (2014) 'Performance Assessment of Maintenance Practices in Government Office Buildings: Case Study of Parcel E, Putrajaya', MATEC Web of Conferences, pp. 10: 1-7.

[57] Waziri, Baba Shehu. (2016). Design and Construction Defects Influencing Residential Building Maintenance in Nigeria. Jordan Journal of Civil Engineering. 10. 313-323. 10.14525/JJCE.10.3.3605. 